\title{
Prophecy and Religion Revisited: John Skinner and Evangelical Biblical Criticism
}

\author{
Walter J. Houston
}

Citation: Houston, Walter J. 2021. Prophecy and Religion Revisited: John Skinner and Evangelical Biblical Criticism. Religions 12: 935. https:// doi.org/10.3390/rel12110935

Academic Editor: Bradford A. Anderson

Received: 20 September 2021

Accepted: 18 October 2021

Published: 28 October 2021

Publisher's Note: MDPI stays neutral with regard to jurisdictional claims in published maps and institutional affiliations.

Copyright: (C) 2021 by the author. Licensee MDPI, Basel, Switzerland. This article is an open access article distributed under the terms and conditions of the Creative Commons Attribution (CC BY) license (https:// creativecommons.org/licenses/by/ $4.0 /)$.
The Centre for Biblical Studies, Department of Religions and Theology, University of Manchester, Oxford Road, Manchester M13 9PL, UK; walter.houston@mansfield.ox.ac.uk

\begin{abstract}
The paper is an essay in the history of interpretation. Its subject is John Skinner's book on the life of Jeremiah, Prophecy and Religion (1922). The main aim is to place the work in its historical, theological and cultural context, to explain Skinner's conviction that Jeremiah's life marks the emergence of personal religion in Israel and points towards Christianity. Attempts at such contextualization by J. Henderson and M.C. Callaway are studied and shown to be inadequate. Skinner's religious context and theological education are then reviewed and are shown to be sufficient to account for his belief in the pivotal role of Jeremiah in the evolution of 'religion'. The paper finally addresses the present-day significance of Skinner's work and concludes that while Prophecy and Religion is of limited value for the interpretation of Jeremiah, Skinner's life and work as a whole as an evangelical believer engaged in radical biblical criticism is a valuable model neglected over the last 100 years.
\end{abstract}

Keywords: history of interpretation; Skinner; John (1851-1925); Jeremiah; Henderson; Joe; Callaway; Mary Chilton; Polk; Timothy; prophecy

\section{Introduction}

The year 2022 marks the centenary of the publication of John Skinner's Prophecy and Religion (Skinner 1922), a study of Jeremiah that was successful and influential in its day and for many years afterwards. Skinner, after a ministry in the Free Church of Scotland, was Professor of Old Testament Language, Literature and Theology at the English Presbyterian College, at first in London from 1890 and from 1899 at Westminster College, Cambridge, becoming Principal from 1908 to 1922, and dying in 1925 (see also below). His ICC commentary on Genesis in its posthumous second edition (Skinner [1910] 1930) is still worth consulting and has not yet been superseded. Prophecy and Religion would have been regarded as an equally important work up to the 1970s, but is now widely forgotten. (For example, it does not figure in the bibliographies or index of Crouch 2017).

The book was still on reading lists in 1979 when I succeeded to Skinner's position teaching Hebrew and the Hebrew Bible at Westminster. I would have bought it then, if I had not done so earlier, and it has remained on my shelves ever since. In 1978, rather over its half-century, Peter Ackroyd had devoted an article to it as the first in a series on 'Biblical Classics' in the Expository Times (Ackroyd 1978). He identified the book as a classic in the sense of 'a book which shows perception and sensitivity, a book which ... is most distinctive in its enrichment of the reader's own perceptions', despite the fact that 'so much of the book's approach to its theme is now outmoded' (pp. 356-57). Ackroyd finds the 'primary enduring significance of what Skinner has written' in his examination of 'the subtle relationship between prophetic calling and religious experience' on the one hand 'and political and social background' on the other (p. 358). Outmoded aspects include Skinner's belief that the book was essentially created by Jeremiah himself, using Baruch as an amanuensis, though he identified much secondary material; his confidence in the reliability of Kings as a historical source; and above all his belief in the very possibility 
of the undertaking represented by his work: writing a life of the prophet on the basis of his book.

About the same time as Ackroyd was hailing the work as a classic, Robert Carroll was attempting to update it, but quickly decided that this had been rendered impossible by more recent trends in the study of Jeremiah. The book owed far more to scribal redaction than to the prophet himself, especially the prophet as a person, and its authors were more interested in the agendas of their own sixth- or fifth-century context, using the words and life of the prophet for their own purposes. The book could not therefore be used to write a life of Jeremiah. Carroll's book From Chaos to Covenant was the result (Carroll 1981). Its approach is an index of how far biblical studies had changed in sixty years. Yet Carroll was still essentially interested in the history of the book, its formation and composition and the intentions of its editors in their own time. In the succeeding forty years, interests in biblical studies have shifted still further, leaving the books' origin and historical context, and meaning in that context, almost entirely behind. Later in this paper I shall consider briefly how Skinner's interest in personal religion may be pursued in the book of Jeremiah today as a literary text rather than as a historical document.

The main object of this paper, however, is to explore the historical and theological context of Skinner's understanding of the book and his resulting portrait of Jeremiah, in dialogue with a couple of recent studies.

\section{Skinner's Case: The Perfection of Religion through Prophecy}

Despite the subtitle and the book's form as a life, the title is more significant: Prophecy and Religion. It is Skinner's object to show that Jeremiah's calling as a prophet and the experience of his life in that role enabled a major advance in religion that prepared the way for Christianity. Understanding 'religion' as a relationship between God and human beings, he observes that 'the Old Testament religion ... is a relation between a personal Being on one side and a national entity on the other' (Skinner 1922, p. 6). It is a national religion, in which individuals are included by default and without any necessary personal commitment. Within it, prophets exercised the role of intermediaries (p. 7). But to Skinner a higher form of religion is personal religion, the individual and unique relationship in which 'God enters into immediate fellowship with the human soul' (p. 14). It is this that Jeremiah gained through his prophetic experience; not merely gained, but also proclaimed, though without going beyond Israel as the sphere of such religion.

Historical events brought it about that in Jeremiah's time 'the time had come for State and State-religion to be done away' (p. 258), not of course the state as an institution in the world of nations, but the specific nation of Israel expressed for now in the state of Judah, so that the religion of Israel had to take other forms. However, long before this, Skinner believes, Jeremiah had become disillusioned with the forms in which the state religion was expressed. He had supported the reform of Josiah: this is what is intended by the covenant which Jeremiah is commanded to preach in chapter 11 (pp. 102-03). However, he had very soon realized, according to Skinner, commenting on Jer 8:8, that the implementation of the covenant had resulted in complacency and mere formality in religion, a reliance on rites rather than on moral obedience and commitment. 'Jeremiah began to suspect the inherent impotence of the legal method of dealing with national sin' (p. 106). Further, he came to the realization, expressed in the so-called Temple Sermon (Jer 7:4, 8-15* as reconstructed by Skinner, 170-71; cf. 26: 4-6) that 'public religion, the religion of which the Temple is the centre and symbol, is an organised hypocrisy' (p. 175), while sacrifice, the central rite of worship in Israel and among virtually all nations at the time, was not only useless if offered by impenitent sinners, but was never asked for by God in the first place (Jer 7:21-23, as interpreted by Skinner, pp. 181-82). The Temple and ritual were 'a perversion of the historic religion of Israel from its native ethical genius' (184). Skinner affirms that 'To Jeremiah religion was reality-real fellowship with a real moral deity, and whatever obscured that relationship was a hindrance to religion and must be swept away (p. 177). 
It was Jeremiah's experience as a prophet that brought him into a personal relationship with God which would be the form in which the religion of Israel would survive. This relationship is best expressed, in Skinner's understanding, in the so-called confessions of Jeremiah, the series of poems scattered through chapters 11 to 20 in which the unnamed poet, who in the context has to be understood as Jeremiah-Skinner, of course, assumes it is Jeremiah-addresses YHWH in the form of psalms of lamentation. (Skinner's translations of these poems are to be found in Skinner 1922, pp. 110-11, 203-8).

Skinner sums up the introduction to his chapter on the confessions (entitled, significantly, 'Individual Religion - the Inner Life of Jeremiah') by stating: 'We shall find here a certain expansion or sublimation of the prophetic consciousness into the larger relationship which is properly called religion' (p. 203). Although the prophetic call is itself a religious experience, it was limited in scope to the dealings of $\mathrm{YHWH}$ with Israel, and left unsatisfied Jeremiah's personal needs for justification and a sense of success. In such a situation, Skinner argues, a prophet must either fall into despair, 'or else he will find in himself, in his own assent to [the] truth [of the word of God] and his sense of its imperishable worth, the germ and pledge of a new religious relationship' (p. 219). His protests and prayers, and the answers which he occasionally receives, constitute for Skinner the essence of true religion: it is a relationship which touches the depths of the prophet's soul and not solely his responsibility to condemn and warn his people.

The enduring significance of Jeremiah's work lies for Skinner in his revelation of personal religion, fellowship between God and the individual, as 'the future of religion' (the heading of his last four chapters), for Israel and ultimately for the world. Of the four chapters, those dealing with the letter to the exiles of 597 (Jeremiah $29^{*}$ ) and the new covenant (Jer 31: 31-34) are the more significant in this regard.

Skinner identifies Jer 29: 5-7, 11-14a (נאם-יהוה) as the original letter to the exiles (pp. 287-88). He omits the promise of return from exile after seventy years, taking this to be the work of an editor. The brief oracle thus isolated first encourages the exiles to regard themselves as settled citizens of Babylon, and then assures them of YHWH's care for them where they are, and YHWH's availability for prayer. Skinner concentrates attention on this last theme, that of the undiminished opportunity for prayer in a foreign land. He concedes that this idea was not in itself new, but argues that what is new is that Jeremiah asserts 'that in the privilege of prayer the whole reality of religion is theirs: that in the impending destruction of the externals of their nationality-the Temple, the sacrifices, the Holy City-God still lives, and having intercourse with him, they have all ${ }^{\prime}$ (p. 290, my italics).

However, though Skinner does not bring this out, this does not necessarily imply that converse with God must be on an individual basis. Jeremiah addresses the exiles as a community, and it is this community that is to 'seek him with all your heart' (Jer 29:13). The same is true of the prophecy of the new covenant; yet Skinner treats this as an essential charter of individual religion. As regards its authenticity, he admits that it is not certain that Jeremiah used the concept of covenant, and has to mount an argument to attempt to show that he did (pp. 320-27). In the end, it is simply the importance of the passage in the New Testament and his conviction that it announces 'a new and final stage in God's purpose of redemption', and no more objective criterion, that convinces him that 'It must have been written by Jeremiah' (p. 332). Note how subjective is this final step in his argument for Jeremiah as the herald of a higher stage of religion.

He must acknowledge, for it is obvious, that the 'new covenant' is addressed to the same people, and imposes the same obligation to observe the Torah, as the old one. Skinner argues that even the old covenant, while conserving the 'national principle in religion', 'nevertheless individualised' people, as each person was individually responsible for observing it, and it was finally ineffective because of 'the perversity of the individual will' (p. 326). What then makes the new covenant new?

Skinner identifies three 'positive features' of it: '(1) Inwardness: "I will put My law in their inward part"; (2) Individualism: "all shall know Me"; (3) Forgiveness of sins: "their sins 
I will remember no more"' (p. 329; Skinner's enumeration and italics). He emphasizes the first as the 'central truth' and he other two as secondary. Yet he describes this 'inwardness of true religion' as 'the spiritual illumination of the individual mind and conscience', hence there is no real difference between 'inwardness' and 'individualism'. However, it is not entirely clear why the phrase 'they shall all know me' should imply individualism. Everyone possesses the knowledge of $\mathrm{YHWH}$, but they do so as members of the community and not as isolated individuals. That Skinner should take it for granted that it does imply individualism is characteristic of his approach. It is this that needs explaining historically and theologically. To him,

The individualism of Christianity is not a secondary and incidental feature: it is of the essence of the Gospel. It affirms the infinite value of the individual soul, its potential freedom ... and its capacity for realising that freedom in communion with the Father of spirits. (pp. 333-34)

Hence, if Jeremiah's new covenant implies individualism, it indeed points the way forward to 'the perfect religion'. To the objection raised by Duhm that if the passage were genuinely Jeremiah's, he would be proposing, not a new covenant, but a new Torah, as the old one was full of the legal and ritual material that Jeremiah rejected, Skinner responds that Jeremiah '(and perhaps the prophets generally)' had always understood Torah not as the literal contents of a code, but as 'the revelation of the essential ethical will of God', partly expressed in codes or the prophetic message, but transcending them (p. 332). In this sense no new Torah was required. What was required was the understanding of it by all, and their commitment to it. This is what Jeremiah describes as a 'new covenant'.

\section{3. 'Inventing' Jeremiah: Jeremiah as Liberal Theologian?}

The fading of Skinner's influence in the later twentieth century did not mean the end of any interest in his book. A volume appeared in 2015 entitled Jeremiah Invented: Constructions and Deconstructions of Jeremiah (Callaway 2015). The first two essays in this collection mention Prophecy and Religion. The first deals at length with it, and attempts to place Skinner's portrait of Jeremiah against his intellectual background.

Joe Henderson pairs Skinner with Bernhard Duhm, whose commentary on Jeremiah (Duhm 1901) pioneered the method of reconstructing the history of the prophetic books' composition by reference to literary form and style (Henderson 2015). To a large extent, Skinner followed Duhm in identifying the poetry of the book as the authentic core of Jeremiah's prophecy: prophecy as poetry is an idea which Henderson traces to Lowth and Herder and the Romantic movement which they presaged. Skinner's view of Jeremiah's life is also shared with Duhm: 'a sensitive rural poet whose spiritual insight enabled him to break through to authentic personal religion' (Henderson 2015, p. 2). However, Henderson notes that for Skinner what he deemed theological insight was even more important than poetic form for the discernment of the authentic utterances of Jeremiah: as we have seen, Skinner takes the alleged theological profundity of Jer 31: 31-34 as evidence that only Jeremiah could have written it, even though the passage is prose. Henderson takes the contrast implied here between authentic religion and Jewish legalism as an instance of the general view in nineteenth-century liberal theology of the history of religion, and of the Hebrew scriptures as 'treasure buried in a trash heap'. He quotes from Harnack's What is Christianity?: 'The spring of holiness had long been opened; but it was choked with sand and dirt ... the rubbish which priests and theologians had heaped up so as to smother the true element of religion' (Henderson 2015, p. 4; Harnack 1901, p. 52).

Henderson then proceeds, much more surprisingly and intriguingly, 'The biography of Jeremiah produced by Duhm and Skinner bears a remarkable likeness to the accounts of crises of faith that were a widespread phenomenon of the nineteenth century in novels and biographies' (Henderson 2015, p. 5). He lists the standard elements in these stories: 'pious youth in the shelter of traditional faith, early religious enthusiasm . . , disillusionment; erosion of traditional beliefs through exposure to modern scientific, historical, and critical studies; painful break from family and church; discovery of deeper personal and moral 
religion; and steadfast endurance of opposition from church and traditional institutions.' He says this pattern often appears in the lives of liberal theologians and historical critics, citing among theologians Schleiermacher, Ritschl, and Harnack. Among biblical scholars, he cites de Wette for a personal crisis of faith; for rejection and alienation, Colenso; for fidelity to a personal scholarly vision against opposition, Ewald and William Robertson Smith (pp. 5-6).

As for Skinner's Jeremiah, Henderson refers for his 'crisis of faith' to the passage I quoted myself above: 'Either the prophet will despair of religion ... or else he will find in himself, in his own assent to [the] truth [of the word of God] and his sense of its imperishable worth, the germ and pledge of a new religious relationship' (Skinner 1922, p. 219). He then narrows the argument to a comparison with the theologians and biblical critics he has just referred to, and argues that the parts of Israel's religion that Jeremiah rejects, according to Skinner, are 'practically identical to the parts of orthodox Christianity that liberal theologians and biblical critics came to doubt' (Henderson 2015, p. 6). He refers to Jeremiah's 'loss of faith in the Deuteronomic reform and his loss of faith in the sacrificial system.' As to the former, Skinner argues that Jeremiah saw the problem as trust in a written word of God, rejecting the illusion of infallibility and finality attaching to the written word, as if it were superior to the living voice of prophecy or the dictates of the religious sense' (Skinner 1922, p. 121; Henderson 2015, pp. 6-7). As to the latter, Jeremiah sees that sacrifice is not essential for fellowship with God, and was never commanded by God in the first place. 'In short', Henderson concludes, 'the great crisis of Jeremiah's life is his conversion to the Grafian view of the Mosaic Law and Protestant liberalism's view of salvation, its characteristic rejection of sacrificial, or substitutionary, atonement' (p. 7). 'He realizes that the priestly legal materials were not part of the original revelation but were added by later editors', and uncovers 'the true history of Israel's religion' (p. 7, referring to Skinner 1922, p. 184). 'These historical-critical insights allowed Jeremiah to come close to the pure ethical religion of Ritschl and Harnack, built on his recognition that "a perfect religious relationship is possible without sacrifice at all"' (Henderson 2015, p. 7, quoting Skinner 1922, p. 181).

Henderson thus moves to his conclusion, building on an observation by Leo Perdue that Skinner's Jeremiah is 'something of an Adolf von Harnack' (Perdue 1999, p. 321):

The anachronistic nature of their [Duhm's and Skinner's] results raises questions about the objectivity of their initial assumptions ... The Skinnerian biographer [Henderson neatly sidesteps the danger of being unfair to Skinner himself] could say: 'In the massive stone of the book of Jeremiah, I saw the figure of a liberal theologian waiting to be freed. Then my task was easy; I simply chipped away whatever didn't look like Harnack. (Henderson 2015, p. 8)

This preposterous conclusion raises questions about Henderson's own objectivity. Apart from anything else, it contradicts an elementary point that is always at the forefront of Skinner's mind: Jeremiah was not a theologian of any kind, let alone a biblical scholar, but a prophet. It is as a prophet that Skinner sees him denouncing the reliance on sacrifice (7: 21-23) and on written documents (8: 8) (Skinner 1922, pp. 121, 176-83). It is natural in such reconstructive efforts that the reconstruction will owe more than a little to the beliefs and personality of the scholar., It is undeniable, nevertheless, that Jeremiah as presented in the book of Jeremiah does utter these thoughts, so Skinner's portrait of Jeremiah is not totally unrelated to the evidence, even if he was mistaken in believing it corresponded to the Jeremiah of history. Above all, Skinner is far more interested in the significance of Jeremiah for 'the future of religion' than in his estimate of its past. Of this positive aspect of Jeremiah's faith journey and proclamation in Skinner's portrait, Henderson makes nothing but the provocative suggestion that the portrait rather resembles Harnack.

A number of false steps lead Henderson to this conclusion. First, in discussing the 'crisis of faith' narrative, he is clearly unable to show that the lives of most of the biblical scholars cited exhibit the pattern, which is why he apportions elements of it among different scholars. Apparently, only de Wette underwent a personal crisis of faith (Rogerson 1992). 
Certainly neither Colenso (Rogerson 1984, pp. 220-37) nor Smith did so. Smith, in particular, is notable for his persistence in the evangelical faith and piety in which he was brought up, despite his thoroughgoing embrace of the Graf/Wellhausen/Duhm model of Israel's religious history (Rogerson 1995, pp. 55-162, esp. 130-62; Maier 2009, pp. 277-79). The same would be true of Skinner himself, who is called by one of his former students the saint of Westminster' (Robson 1956, p. 15), while another says of him,

In the midst of the maze of variant sources from which his Old Testament was compiled, he moved alert and masterful in order to read that word of God which is there for the eyes that see and the ears that hear... Older people who were once scared at some of the results of his scholarship would believe that anything he said must be the word of God, when they heard him conducting household prayers. ('J.F.' 1925)

It is also hard, in a different way, to see the young Harnack as undergoing a 'crisis of faith', since at every stage he appears confident of what he believed, and of what of his father's faith he did not accept (Glick 1967, esp. 23-53). Henderson's move strikes me as an unfair, although transparent, manipulation of the evidence.

He makes a more serious error in citing Skinner's words about Jeremiah's crisis. The crisis Skinner describes in no way resembles the crises in the lives of the real and fictional nineteenth-century characters cited by Henderson. Those crises were triggered by intellectual challenges and posed the choice between faith and unbelief, leading to the refashioning of faith. Jeremiah's crisis as imagined by Skinner is triggered by the people's rejection of his prophetic message and poses the choice between despair and hope, leading to the discovery of deeper resources within the faith that he has always held and continues to hold. 'Disowned by men and driven in upon himself, he found in the truth of his rejected prophecy an indissoluble link of communion between his own soul and God' (Skinner 1922, p. 219). Henderson proceeds, inconsistently, to refer to earlier passages, which speak of what Skinner understands as earlier episodes in Jeremiah's career, his rejection of trust in a written word and in sacrifice (Henderson 2015, pp. 6-7). This cannot be explained by a subsequent 'crisis of faith'. In any case, the intellectual move made here by Jeremiah cannot be described as 'loss of faith' in the sense at issue. Skinner never says that Jeremiah at any time centred his faith on the Deuteronomic reform or on any written scripture such as (an early form of) Deuteronomy, still less on the sacrificial system. 'He had never imagined that sacrifice was of the essence of religion' (Skinner 1922, p. 184). Jeremiah's 'crisis of faith' is not Skinner's invention but Henderson's!

Despite this, Henderson may still be correct in characterizing Skinner's Jeremiah as holding analogous views, in respect only of the rejection of tradition, to a nineteenth- or twentieth-century liberal theologian such as Harnack, but he hardly does his case any favours by sarcastically describing him as being 'converted to the Grafian view of the Mosaic Law and Protestant liberalism's view of salvation.' Skinner as a good Wellhausenist believed that the only part of the Mosaic Law that existed in Jeremiah's day was Deuteronomy. His Jeremiah does not express any views about the Priestly code, only rejecting the comparatively minor ritual parts of Deuteronomy as no part of divine revelation (p. 183). This is not a view about a canon that only came into existence at a much later date, nor even in essence about the authority of written texts, but about the insignificance of ritual to religion as fellowship with God, Skinner's definition. It is a considerable stretch to argue that this view of ritual is in some way analogous to the rejection of substitutionary atonement in Christian faith. The issues are entirely different, and the understanding of ritual as necessary to maintain relationship with God is of course rejected by all Protestants, not only liberals. Moreover, the nineteenth-century debate over the atonement was a debate between evangelicals, not between defined groups of evangelicals and liberals. (For an example, see Calderwood and Woodside 1900, pp. 258-74). It is only the hardening of the lines in the twentieth century that has misled Henderson into thinking that the rejection of substitution is a marker for liberalism. 
What is one to say about the picture of Skinner as a latter-day Michelangelo releasing the angel of his vision from a block of Carrara marble? It is fair to say that a scholar engaged in creative reconstruction has something of the artist about him, and that 'the result was in some measure due to the scholar's original perception of the prophet' (Henderson 2015, p. 8): but to insinuate that the result was shaped altogether by that perception and owed nothing to the structure of the marble, that is, to the evidence of the book, goes far beyond fair dealing.

\section{Skinner in Context}

How may we more accurately describe the genesis of the Jeremiah portrayed in Prophecy and Religion?

In the second, more wide-ranging essay in Jeremiah Invented (Callaway 2015), Mary Chilton Callaway, in the course of an account of historical-critical work on Jeremiah, describes Skinner as using 'the discourse of evolution to present Jeremiah to the Englishspeaking world as a spiritual turning point in the development of humanity's relationship to God' (p. 21). She homes in on Skinner's account of the so-called Confessions, quoting a long passage where he presents these psalmodic passages as the 'reaction of [Jeremiah's] human subjectivity on the fact of his prophetic call[,] which unsealed within him the perennial fountain of his piety - the religious receptivity of the individual' (Skinner 1922, p. 223). She then goes on to say that 'Skinner cast him in the language of seventeenth-century English devotion' (Callaway 2015, p. 22). His description of 'a life of prayer and communion, in which all that concerned him ... formed the subject of an intimate introspective dialogue between himself and the divine voice' evokes for Callaway 'the religious sensibilities of the metaphysical poets of seventeenth-century England, epitomized by John Donne and George Herbert.' She points out that Skinner's book was published about the time when these poets were being rediscovered. Jeremiah's confessions were for him 'a turning-point in the development of human consciousness, characterized essentially by seventeenth-century English spirituality' (p. 22).

I fancy that this characterization would come as a surprise to Skinner, even though he might recognize the commonality between such a prayer as Jer 20: 7-12 and 'Batter my heart, three-personed God.' Certainly Callaway cites no evidence that Skinner knew the metaphysical poets. (Incidentally, it would be a nice exercise to work out what John Donne and Adolf von Harnack had in common.) However, at least Callaway's probe is more in the right direction than Henderson's: it is focused on the spirituality that Skinner attributes to Jeremiah, and on his positive contribution to 'religion.'

To approach this question productively, it would be well to start by looking at Skinner himself, and his background. We do not know much about his early life, but we can safely conjecture something on the basis of the known facts. He was born in 1851 in Inverurie in Aberdeenshire (a prolific mother of biblical scholars), and studied at the University of Aberdeen, graduating in 1876, and then at the Free Church College there and at New College, Edinburgh, also a Free Church foundation, being ordained at St Fergus back in Aberdeenshire in 1880 (Anonymous 2021, using as source, among others; Ewing 1914, vol. 1, p. 318). We can therefore be confident that he was brought up in the Free Church of Scotland. At the time of his birth, this church was only eight years old, having been formed when most of the evangelical party in the Church of Scotland, including at least a third of its ministers, left the church in 1843 over the issue of the imposition of ministers on unwilling parishes by their patrons. He would have been brought up in an atmosphere of evangelical piety of a characteristically Presbyterian kind. What this involved can be studied in numerous nineteenth-century biographies. Household prayers, centred on the reading of the scriptures, would have marked the beginning and ending of each day, but it would have been borne in on the growing lad, not least through his required study of the Westminster Catechism, that his ultimate salvation depended on his making a personal commitment to the Lord Jesus Christ, leading to a life of personal prayer, devotion, and obedience. In Skinner's case this evidently led further to a call to the 
ministry. The life of the congregation, centred on the local Free Kirk, was a third order of spirituality outside the circles of the individual and the family, but very important for the preaching of the Word and exposition of Scripture. Its highest expression would have been the twice-yearly 'communion season'. This culminated in the communion service, but this was led up to by a series of preparatory services, at which the members of the congregation would be exhorted to examine themselves, repent of their sins and ensure they were in a fit state to receive the sacrament, 'giving diligence to make their calling and election sure' (2 Pet 1:10 KJV). The individual was personally responsible for this exercise: no priest would hear their confession. Being a member of the visible church would open the means of grace to them, but, according to the Westminster Catechism, it was not an assurance of salvation. (Westminster Larger Catechism [1647] 1959, Q. 61).

Need we look any further for the source of Skinner's conviction that the highest form of religion was personal, the individual and unique relationship between God and an individual? The same goes for his belief in the inessentiality of ritual to that relationship, and for his assertion that 'in the privilege of prayer' the exiles possessed 'the whole reality of religion' (Skinner 1922, p. 290).

It may be asked how this faith and piety could be combined with an acceptance of a radical historical criticism rejecting the Mosaic origin of the Pentateuch and seeing substantial parts of the book of Jeremiah as redactional. This is easy to explain. He must have studied for the ministry between 1876 and 1880, first at the Free Church College in Aberdeen and then at New College, Edinburgh. He took his first year of theological study at the Aberdeen college (Black and Chrystal 1912, p. 574 n. 2), and the remaining two years at New College: he describes himself as a second-year student in November 1877 when he first saw and heard Professor A.B. Davidson (Skinner 1902, p. 248). He also studied in Germany, probably in his third year, at Leipzig and Göttingen ('J.F.' 1925). He will therefore have studied first with Robertson Smith in the last year in which he was permitted to teach, and then with A.B. Davidson, who had been Professor of Hebrew and Old Testament at New College for many years. Smith, like Skinner, had studied under Davidson, and Davidson was an adherent of what was then known as the higher criticism, or simply criticism, but was never publicly outspoken about it in the way Smith became. He was censured for his reticence, especially when he failed to speak out in support of Smith at the time of his arraignment on charges of heresy (Bruce 1896). His biographer argues that he disapproved of Smith's blunt pedagogical approach in relation to his church (Strahan 1917, pp. 238-42). However, it was clear enough to his students what he taught. Skinner speaks of 'the subtle and stimulating influences that played on the minds of his hearers, and silently revolutionized the thinking of many of them' (Skinner 1902, p. 248). It was clear to others also: Black and Chrystal comment on a review article by Davidson in 1879 , 'It is clear, though he does not say so in so many words, that the scholarly reviewer disbelieves in the Mosaic authorship of Deuteronomy' (Black and Chrystal 1912, p. 339).

Like Smith, Davidson retained his evangelical faith and piety. Skinner says of Davidson, 'Criticism was to him no concession to an alien and irreligious tendency of mind; it was a product of the true religious spirit; it was the effort of exegesis to be historical, "just that we may trace God's historical fellowship with mankind"' (Skinner 1902, p. 250. The unattributed quotation is presumably from Davidson himself.). Smith in his turn saw no inconsistency between his evangelical piety and his understanding of the development of the scriptures and of Israel's religion. Both understood their faith in historical terms which accorded with the intellectual atmosphere of the late nineteenth century. In Smith's first lecture at the Aberdeen College, he affirmed:

If we desire to deal truly with Scripture and our Protestant freedom, we must regulate all our exegesis and all our criticism by the great principle that we are to seek in the Bible, not a body of abstract religious truths, but the living personal history of God's gracious dealings with men from age to age, till at length in Christ's historical work the face of the Eternal is fully revealed, and we by faith can enter into the fullest and freest fellowship with an incarnate God. (Smith 1912, pp. 229-30) 
Skinner had evidently thoroughly absorbed the teaching of his professors, and it was therefore easy for him to integrate Duhm's approach to Jeremiah into his scholarly toolbox when Duhm's commentary was published in 1901. Moreover, if he was at Göttingen in the academic year 1878-79, he would already have encountered Duhm, who was in his second year as außerordentlicher Professor (Rogerson 1984, p. 143), and would probably have been encouraged to go to his lectures by his teachers at home.

We have already noted that Skinner presented Jeremiah in the context of an evolutionary understanding of religion. Some years before the publication of Prophecy and Religion, he read a paper, eventually published as a pamphlet, entitled The Evolution of Religion in the Old Testament (Skinner 1910). His high estimate of individual religion is bound up with this evolutionary concept, and yet he was able to combine it with a belief in special revelation. In effect, he saw God as graciously measuring out revelation in step with what people in each successive era were able to understand and receive.

The time came .... when [Jeremiah's] private relation to God ... broadened out into the conception of a new community of the people of God, based on direct personal knowledge of God such as he alone at this time possessed. Nevertheless, both in his experience and in the history of revelation, individualism was a necessary stage towards the formation of the new humanity whose Head is Christ. (Skinner 1922, p. 224)

It was a great step in the history of religion to turn from the formalism of external worship, and the legalism of a national covenant, and to find God in the heart of the individual ... By the grace of God Jeremiah took that step, and opened up a way of access to God which many devout souls, following in his footprints, found to be the way everlasting. (p. 227)

We might ask whether, in placing Jeremiah at the pivot of this development through individual religion to Christianity, Skinner was overlooking the individual style in the Psalms - and of course at least since Gunkel, and certainly Baumgartner, it has been widely recognized that the so-called Confessions of Jeremiah are examples of the genre of the individual lament psalm (Baumgartner [1917] 1987, pp. 13-17). The answer is that he did not overlook it, but was influenced by the general belief in critical circles at the time that the Psalms largely dated from post-exilic times. This makes sense of his assertion that Jeremiah 'embodies the transition from the prophet to the Psalmist ... [Jeremiah's] life, in which prophecy effloresced, contained the germ of the devotional poetry of the Psalter' (Skinner 1922, p. 222). However, we can today be fairly confident that the psalms had existed long before Jeremiah.

Skinner was by no means alone at the time in assigning this significance to personal religion. Indeed he obviously expected his readers to accept it with little question. His friend and colleague John Oman, his successor as Principal of Westminster College, likewise a Scottish Presbyterian with an evangelical upbringing, shared his emphasis on individual religion and associated it with prophecy, and shared also his evolutionary understanding of religion. 'The standard of its [the Old Testament's] teaching is personal responsibility', he writes, 'and that ultimately sets a man alone as an individual with his God' (Oman 1906, p. 2376; cf. Oman 1931, p. 451). He notes in particular the assertion of an exclusively individual responsibility in Ezekiel. Again, dealing with the New Testament, 'A relation of love in Christ's sense necessarily means a relation of individuals' (Oman 1906, p. 2379). In a later work he begins a section on prophecy with the standard historical-critical assessment of the time that 'the Hebrew prophets were the first true monotheists.' He then proceeds to define monotheism in his own way, and goes on:

What marks off a true monotheism sharply from polytheism is its rejection of the political state as a religious ground of trust, and from ceremonial-legalism its rejection of the national cult as pre-eminently God's service. For the prophets, faith does not depend on nation or church but nation and church upon faith ... 
God's order is thus seen to depend on the relation of the individual soul to him.

(Oman 1931, pp. 449-50)

Of course, we cannot limit the context in which Skinner writes to his experience in evangelical Presbyterianism, together with the late nineteenth-century acceptance of historical criticism and evolutionary thinking. Charles Taylor shows in his monumental work Sources of the Self how our 'modern identity' as 'selves' with a personal will and personal responsibility emerged over the centuries (Taylor 1989). The language of inwardness was crucial for Augustine: here for him was 'the "space" in which we come to encounter God' (p. 140). Taylor quotes a sentence from the Confessions: 'God the light of my heart, and the bread that nourishes my soul, and the power which weds my soul to my inmost thoughts' (Augustine Confessions: 1.13.21 (Deus lumen cordis mei, et panis oris intus animae meae, et virtus maritans mentem meam et sinus cogitationis meae)). Later, he identifies three facets of the 'nascent modern individualism' in process of development by the beginning of the eighteenth century: 'self-responsible independence', 'recognized particularity', and 'personal commitment' (Taylor 1989, p. 185). This last aspect, though foreshadowed in Augustine's emphasis on sin as the weakness of the will, became of particular importance in the Protestant Reformation. Here the duty of total commitment, formerly considered the preserve of an elite, was extended to every Christian. Because salvation is totally the work of God, it cannot be mediated to the individual by the institution of the church or a caste of priests. Every person stands alone before God. 'One no longer belonged to the saved, to the people of God, by one's connection to a wider order sustaining a sacramental life, but by one's wholehearted personal adhesion.' (p. 217). This resulted in the activities of 'ordinary life' — work and marriage and the family — engaged in by ordinary Christians, becoming the site of their commitment. This doctrine was in principle maintained by Protestantism in general, but with especial strength in the Reformed or Calvinist stream. Striking examples are quoted by Taylor from English and American Puritanism (pp. 221-27), This brings us back to Skinner, as English Puritanism and Scottish Presbyterianism are branches of the same tree.

\section{Prophecy and Religion Today}

It remains to ask whether Skinner's work, thus placed within its historical context, is of merely historical interest, or whether it still has value for today's readers. In principle it should, for, as Taylor shows, we are very much the inheritors of the individualism developed in the Reformation and Enlightenment. It may no longer be possible to maintain what was taken for granted by Skinner, that the book of Jeremiah offers us a reliable source, if judiciously read, for the veritable life and thought of the prophet. However, does it not give a dramatic picture of an individual, indeed specifically of a prophet, in passionate dialogue with their God? And is Skinner a helpful guide to it?

Timothy Polk gives an emphatic 'yes' to the former question, and an equally emphatic 'no' to the latter (Polk 1984). 'Skinner's sketch of the prophet is not the same as the text's' (p. 12, Polk's italics). It is 'rooted no more in the text than in an idealist metaphysics and a religionsgeschichtliche thesis' (p. 11). Skinner presumes the theological conclusion of the study at its outset. Polk quotes from his introductory chapter: 'Now this discovery of individual fellowship with God which is Jeremiah's great contribution to the religious experience of the Jewish Church is also the clue to his own spiritual biography' (Skinner 1922, p. 16, quoted by Polk 1984, p. 13). Polk argues, using Skinner's terms, that "'personal religion", in the sense of "individual fellowship with God", is assumed by the text, not argued [for] or justified as something new or unheard of ', and further that the text does not indicate such a 'categorical opposition' between national and personal religion as Skinner implies (p. 13, Polk's italics). The prophet is always presented in terms of his vocation, which he exercises corporately, but it involves him personally (p. 13).

Recalling Ackroyd's characterization of Prophecy and Religion as 'a book which shows perception and sensitivity, a book which ... is most distinctive in its enrichment of the reader's own perceptions', we may ask just how perceptive it is if it turns out to be so far 
astray in the matter of Jeremiah's historical significance. Now, to be fair to Skinner, I do not think Polk is correct to assume that personal religion would be argued for or justified if it were something new. It is not the sort of thing that could be argued for, it simply has to be experienced. However, in point of fact it was not something new, as we have seen. Nor is it true that Skinner's 'categorical opposition' between national and personal religion excluded the particular standing of the prophet between the two: this seems, on the contrary, to be asserted in Skinner's introductory chapter (Skinner 1922, pp. 6-15).

In the end, the common reader of Jeremiah, a book which casts so much of its material in the form of narratives about the prophet, is never going to be satisfied with Polk's austerely synchronic reading, which attends 'to the prophet as depicted in the text', which is 'to some extent a literary-theological construct', and which he therefore refers to as the prophetic 'persona' (Polk 1984, p. 10, Polk's italics). Nor indeed will they be satisfied with Carroll's dissection of the book into a multiplicity of pieces which have no unity and little or nothing to do with Jeremiah, though gathered under his name (Carroll 1986).

Now it must be acknowledged that Skinner's reading of the book is almost equally atomistic. In order to create his 'spiritual biography' of Jeremiah, he characteristically takes contexts apart and treats verses or small groups of verses found in one context in different parts of his book, as he perceives their respective settings in the life of Jeremiah. An example is ch. 14, which Polk treats as a single context, right up to 15.4 (Polk 1984, pp. 75-102), while Skinner, having dealt with vv. 1-10, adds a note to say that 'the rest of ch. xiv has no bearing on our present subject', splitting it into no less than four sections, two of which have already been dealt with (Skinner 1922, pp. 128-31,131 n. 1). This apparently cavalier treatment of the text may be justified, quite apart from Skinner's own motivation of creating a biography for Jeremiah, by the widespread recognition that these longer contexts have been built up by redactors, typically adding interpretations and preaching to an original nucleus, as explained, for example, in Douglas Jones's commentary (Jones 1992, pp. 17-37; cf. e.g., Bright 1965, p. 103; McKane 1986, pp. 324, 326, 327, etc.).

The perceptiveness for which Ackroyd commends the book, and its permanent value, may therefore be found not in the finally vain effort to construct a biography for the prophet Jeremiah, nor in the overreach of assigning him a central place in the entire religious history of the West, but in the interpretation of the text in its individual units as the irreducibly personal response of a prophet pressed between the crisis of his nation and what he perceived as the demands of his God.

There is a broader lesson for the present day, however, in our study of biblical interpretation a hundred years ago. Today there is a great gulf fixed between self-described 'evangelical biblical scholarship' and 'liberal' or 'critical' scholarship. The General Editor's preface in any volume of the New International Commentary on the Old Testament states that

[Evangelicalism's] heart and soul is the conviction that the Bible is God's inspired Word, written by gifted human writers, through which God calls humanity to enjoy a loving personal relationship with its Creator and Savior ... NICOT delicately balances "criticism" (i.e., the use of standard critical methodologies) with humble respect, admiration and even affection for the biblical text. (Hubbard 2020, p. xii)

Skinner would have agreed with every word of that. Yet in practice, writers in the series exclude from the application of 'standard critical methodologies' any results, of the kind Skinner was happy to accept, that suggest that the 'gifted human writers' may have included anonymous editors and redactors. In general, commentators on the prophetic books argue that the named prophet wrote virtually the entirety of the respective book. The writer on Amos, in his scholarly and perceptive commentary, tacitly reserves the word 'critical' for interpretations, which he attempts to refute, that deny the authorship of Amos to various passages (Carroll Rodas 2020, passim). Evidently he does not see himself as a critic, although he could with justice be regarded as the leading scholar on Amos of our day. (I am far from disputing the value in every other respect of much of the best evangelical scholarship.) 
In this way, what is usually termed 'mainstream' scholarship is excluded from being considered as evangelical, and, perhaps in reaction, 'mainstream' scholarship has drifted further and further away from a stance of faith. Yet who in the long run is going to be interested in studying the Bible other than believers, Jewish or Christian, whether evangelical or not? These observations apply just as much to synchronic, literary or theological, approaches that are theoretically more open to evangelical scholars (Hubbard 2020, p. xii).

The Church at least, if not academe, needs scholars who are believing critics, able like Skinner to accept the complex truth of the Bible's human origins, and at the same time, in the words once more of his student J.F., 'to move alert and masterful in order to read that word of God which is there for the eyes that see and the ears that hear' ('J.F.' 1925).

Funding: This research received no external funding.

Acknowledgments: The author wishes to express his gratitude to the Academic Editor, Brad Anderson, for accepting this article for publication and wisely guiding him in the revision, to the three anonymous reviewers for their good counsel, and to the Assistant Editor, James Ang, and the staff of MDPI for their work in preparing the article for publication.

Conflicts of Interest: The author declares no conflict of interest.

\section{References}

Ackroyd, Peter R. 1978. Biblical Classics. I. John Skinner: Prophecy and Religion. Expository Times 89: 356-58. [CrossRef]

Anonymous. 2021. Ministers of the Free Church of Scotland 1843-1900: S. Available online: https://www.ecclegen.com/ministers-s / \#SKINNER, \%20JOHN (accessed on 14 August 2021).

Baumgartner, Walter. 1987. Jeremiah's Poems of Lament (tr. David E. Orton from Die Klagegedichte des Jeremia [BZAW 32]. Berlin: Töpelmann, 1917). Sheffield: Almond. First published 1917.

Black, John Sutherland, and George Chrystal. 1912. The Life of William Robertson Smith. London: A \& C Black.

Bright, John. 1965. Jeremiah (AB 21). Garden City: Doubleday.

Bruce, Alexander Balmain. 1896. The Rev. A. B. Davidson, D.D., LL.D., Professor of Hebrew in the New College, Edinburgh. The Biblical World 8: 257-64. [CrossRef]

Calderwood, William Leadbetter, and David Woodside. 1900. The Life of Henry Calderwood. London: Hodder \& Stoughton.

Callaway, Mary Chilton. 2015. Seduced by Method: History and Jeremiah 20. In Jeremiah Invented: Constructions and Deconstructions of Jeremiah (LHBOTS 595). Edited by Else K. Holt and Carolyn J. Sharp. London: Bloomsbury T \& T Clark, pp. 16-33.

Carroll, Robert P. 1981. From Chaos to Covenant: Uses of Prophecy in the Book of Jeremiah. London: SCM Press.

Carroll, Robert P. 1986. Jeremiah: A Commentary (OTL). London: SCM Press.

Carroll Rodas, M. Daniel. 2020. The Book of Amos (NICOT). Grand Rapids: Eerdmans.

Crouch, Carly L. 2017. An Introduction to the Study of Jeremiah (T \& T Clark Approaches to Biblical Studies). London: Bloomsbury T \& T Clark.

Duhm, Bernhard. 1901. Das Buch Jeremia (KHC 11). Tübingen: Mohr.

Ewing, William. 1914. Annals of the Free Church of Scotland, 1843-1900. 2 vols. Edinburgh: T \& T Clark.

Glick, G. Wayne. 1967. The Reality of Christianity: A Study of Adolf von Harnack as Historian and Theologian. New York: Harper \& Row.

Harnack, Adolf von. 1901. What Is Christianity? (tr. Thomas Bailey Saunders from Das Wesen des Christentums. Leipzig: Hinrichs, 1900). New York: G.P. Putnam's Sons.

Henderson, Joe. 2015. Duhm and Skinner's Invention of Jeremiah. In Jeremiah Invented: Constructions and Deconstructions of Jeremiah (LHBOTS 595). Edited by Else K. Holt and Carolyn J. Sharp. London: Bloomsbury T \& T Clark, pp. 1-15.

Hubbard, Robert L., Jr. 2020. General Editor's Preface. Carroll Rodas 2020: xi-xii.

'J.F.' 1925. John Skinner. Reconciliation 205-6.

Jones, Douglas Rawlinson. 1992. Jeremiah (NCBC). London: Marshall Pickering, Grand Rapids: Eerdmans.

Maier, Bernhard. 2009. William Robertson Smith (FAT 67). Tübingen: Mohr.

McKane, William. 1986. A Critical and Exegetical Commentary on Jeremiah, vol. 1 (ICC). Edinburgh: T \& T Clark.

Oman, John. 1906. Individual. In Dictionary of Christ and the Gospels. Edited by James Hastings. Edinburgh: T \& T Clark, pp. $2375-80$.

Oman, John. 1931. The Natural and the Supernatural. Cambridge: Cambridge University Press.

Perdue, Leo G. 1999. The Book of Jeremiah in Old Testament Theology. In Troubling Jeremiah (JSOTSS 260). Edited by A. R. Pete Diamond, Kathleen M. O'Connor and Louis Stulman. Sheffield: Sheffield Academic, pp. 320-38.

Polk, Timothy. 1984. The Prophetic Persona: Jeremiah and the Language of the Self. Sheffield: JSOT Press.

Robson, R. S. 1956. Our Professors. Edited by S. W. Carruthers. London: Presbyterian History Society of England.

Rogerson, John W. 1984. Old Testament Criticism in the Nineteenth Century: England and Germany. London: SPCK.

Rogerson, John W. 1992. W.M.L. de Wette, Founder of Modern Biblical Criticism: An Intellectual Biography (JSOTSS 126). Sheffield: Sheffield Academic. 
Rogerson, John W. 1995. The Bible and Criticism in Victorian Britain: Profiles of F.D. Maurice and William Robertson Smith (JSOTSS 201). Sheffield: Sheffield Academic.

Skinner, John. 1902. Professor A.B. Davidson. Expository Times 13: 248-51. [CrossRef]

Skinner, John. 1910. The Evolution of Religion in the Old Testament (London Society for the Study of Religion). Letchworth: Garden City.

Skinner, John. 1922. Prophecy and Religion: Studies in the Life of Jeremiah. Cambridge: Cambridge University Press.

Skinner, John. 1930. A Critical and Exegetical Commentary on Genesis (ICC), 2nd ed. Edinburgh: T \& T Clark. First published 1910.

Smith, William Robertson. 1912. What History Teaches Us to Seek in the Bible. In Lectures and Essays of William Robertson Smith. Edited by John Sutherland Black and George Chrystal. London: A \& C Black, pp. 207-34.

Strahan, James. 1917. Andrew Bruce Davidson. London: Hodder and Stoughton.

Taylor, Charles. 1989. Sources of the Self: The Making of the Modern Identity. Cambridge: Harvard University Press.

Westminster Larger Catechism. 1959. In: The Confession of Faith, The Larger Catechism, The Shorter Catechism, The Directory for Publick Worship, The Form of Presbyterial Church Government. Edinburgh and London: Blackwood. First published 1647. 